\title{
Rola miejskiego aquaparku XXI wieku w kontekście społeczno-ekonomicznych potrzeb. Analiza problemu na przykładzie Wodnego Parku Tychy
} The role of the urban Aquapark of the 21st century in the context of socio-economic needs. Problem analysis on the example of Tychy Water Park

\section{Streszczenie}

Rozwój społeczeństwa wiąże się z postępem technologicznym, jednak jest również przyczyną chorób cywilizacyjnych. Koniecznym staje się wyznaczenie nowych wyzwań aquaparkom XXI wieku. Czy parki wodne mogą oprócz rozrywki zapewniać naukę i powtórzyć funkcjonalność antycznych pierwowzorów? W ramach studium przypadku (Wodny Park Tychy) stwierdzono, iż łączenie funkcji edukacji z rozrywką nawiązuje do tradycji. Jednocześnie za pomocą grywalizacji architektury umożliwia weryfikację wiedzy poprzez zabawę.

Słowa kluczowe: aquapark, park wodny, centrum edukacyjne, grywalizacja, walka ze stresem, przeciwdziałanie chorobom cywilizacyjnym, jednodniowy urlop

\section{Abstract}

The development of society is associated with technological progress, but it is also the cause of civilizational diseases. It is necessary to set new challenges for the 21st century Aquaparks. Can Water Parks provide, in addition to entertainment, learning and repeating the functionality of ancient prototypes? As part of a case study (Wodny Park Tychy), it was found that combining the functions of education with entertainment refers to tradition. At the same time, using the gamification of architecture, it allows you to verify knowledge through play.

Keywords: Aquapark, Park Wodny Centrum Edukacyjne, Gryjalizacja, Walka with stress, Counteracting civilizational diseases, One-day vacation 


\section{WSTĘP}

Aquaparki XXI wieku ze względu na łączenie wielu funkcji - pływalni jak i centrum odnowy biologicznej, fitness, siłowni, saunarium i wielu innych - są zaliczane do VI kategorii złożoności ${ }^{1}$. Podobnie jak w przypadku szpitali i lotnisk, osiągnięcie najwyższego poziomu w klasyfikacji obiektów wynika przede wszystkim z poziomu skomplikowania funkcjonalnego wymagającego izolowania odmiennych grup docelowych². Nie bez znaczenia pozostaje również konieczność spełnienia najwyższych standardów sanitarnych poprzez obróbkę gazów technicznych i technologicznych. W dodatku, albo wręcz przede wszystkim, wspomniane czynniki należy „opakować” najwyższej jakości architekturą, gdyż obiekty te często stanowią wizytówkę miasta. W odróżnieniu od wspomnianych lotnisk i szpitali, aquaparki spełniają dodatkowe funkcje społeczne i socjologiczne ${ }^{3}$ - wobec czego przeważnie są lokowane w samym centrum lub też w sąsiedztwie stref mieszkalnych, a także rekreacyjnych miasta. Protoplastami lub też niedoścignionymi wzorcami, współczesnych aquaparków są bez wątpienia rzymskie termy wybudowane za czasów imperium. Są one przykładem kompleksowej mieszanki budynków użyteczności publicznej ${ }^{4}$, które zapewniały odnowę biologiczną, rozrywkę, relaks i wzrost witalności. Dziś jednak XXI wiek stawia nowe wyzwania obiektom aquaparkowym. Ich rola zostaje rozszerzona o:

- przeciwdziałanie rozwarstwieniu społeczeństwa, dezinformacji, fake newsom, wzrostowi agresji i przestępczości wśród młodzieży, poprzez sport i edukację,

- zapobieganie odrzuceniu i izolacji, zapewniając rozrywkę każdej grupie wiekowej bez względu na sprawność fizyczną czy mentalną,

- zapobieganie rozwojowi chorób cywilizacyjnych, poczynając od otyłości, stresu, na depresji ${ }^{5}$ kończąc, w ramach ucieczki w jednodniowe wakacje stanowiące zastrzyk pozytywnej energii.

Przedmiotem badawczym weryfikującym możliwość spełnienia tak wygórowanych wymagań stawianych współczesnym obiektom aquaparkowym jest Wodny Park Tychy zlokalizowany w Polsce, w województwie śląskim. Analiza zastosowanych rozwiązań projektowych i funkcjonalnych przedmiotowej inwestycji udowadnia, iż możliwa jest realizacja wszystkich wymienionych wyżej ról i wyzwań. Jednocześnie stanowić może model dla innych inwestycji publicznych zarówno na obszarach miejskich, jak i wiejskich. Poruszone zagadnienia mają na celu poszerzenie wiedzy na temat możliwości drzemiącego potencjału miejsca, w którym planuje się tego typu inwestycje. W czasach nowożytnych przed realizacją Wodnego Parku Tychy nie podjęto się połączenia tak wielu różnorodnych i pozornie rozbieżnych funkcjonalnie stref w jedno centrum rozrywki, nauki i edukacji. Jednocześnie dzięki zastosowaniu współczesnych socjotechnik i cyfryzacji można mówić o nowym poziomie rozwojowym w stosunku do funkcjonalnych wzorów antycznych. 


\section{HISTORIA}

Geneza aquaparków jest głęboko zakorzeniona w historii ludzkości. Jest „plątaniną” kilku nurtów, poczynając od pragmatycznego zastosowania, poprzez oczyszczający, relaksacyjny, religijny, metafizyczny, higieniczny, terapeutyczny, rozrywkowy, aż po społeczno-socjalny. W czasach prehistorycznych ludzkość dysponowała tylko naturalnymi formami oczyszczenia i schładzania się, jak morza, rzeki i jeziora, poprzestając na pragmatycznych korzyściach wynikających z takiego korzystania z wody. Jednak wraz z powstawaniem dużych skupisk ludzkich, przeludnieniem generującym zanieczyszczenie wspomnianych akwenów, koniecznością stało się „ucywilizowanie” kąpieli dla mieszkańców miast.

Obecnie upowszechnione badania wskazują, iż pierwszą publiczną formą zażywania kąpieli była Wielka Łaźnia w Mohendżo Daro w obecnym Pakistanie wybudowaną w trzecim tysiącleciu przed narodzinami Chrystusa. Miasto dysponowało cysterną o wymiarach $11,88 \mathrm{~m}$ na 7,01 m o maksymalnej głębokości 2,43 m, do której prowadziła para schodów po przeciwległych stronach. Łaźnie sąsiadowały z kolegiata kapłanów, co sugeruje nurt religijno-oczyszczający. Ze względu na ograniczoną wiedzę początkowo nie utożsamiano kąpania się z higieną i znaczeniem zdrowotnym, a raczej z siłą, spirytualną odnową, pięknem i kultem.

Kolejny krok cywilizacyjny osiągnęli Grecy poprzez ołowiane rury z punktami czerpalnymi wewnątrz ich domostw i gimnazjonów, które jako pierwsze zostały wyposażone w prysznice. Miejsca te, stanowiące punkt spotkań, sportu, rozrywki i nauki, propagowały masowo ideę rekreacji wodnej wśród społeczeństwa.

Wszystkie wyżej wymienione rozwiązania zostały przejęte, zaimplementowane i rozwinięte za czasów imperium rzymskiego, stanowiąc apogeum rozwojowe publicznych łaźni, a jednocześnie będąc protoplastą dla współczesnych Aquaparków. Termy cesarskie stanowiły apogeum rozwojowe rekreacji wodnej, wykorzystując wszystkie możliwe nurty rozwojowe, łącząc je w jeden olbrzymi kompleks. Obiekty te były przystosowane do grania we wszelkiego rodzaju znane gry zespołowe i kulowe. Po intensywnym wysiłku fizycznym przychodził czas na oczyszczenie. Olejowanie ciała i zdrapywanie brudu i potu. Termy stanowiły miejsce spotkań, uczt i handlu, a wobec tego stanowiły dogodne miejsce agitacji i politycznych dysput. Punktem kulminacyjnym tego kompleksu były pomieszczenia łaźni, saun i basenów oraz miejscem wykonywania masaży. Pomieszczenia te posiadały systemy ogrzewania i chłodzenia zasilane z dalekosiężnych akweduktów. Woda była uzdatniania za pomocą rozgrzanego piasku, który oczyszczał i zabijał bakterie. Zwieńczeniem łaźni rzymskich były oddziały głównych bibliotek, które umożliwiały również plebsowi dostęp do wiedzy i informacji. Wszystkie te czynności były społecznymi rytuałami dzielonymi ze współmieszkańcami, tworząc więzi społeczne i socjalne. Termy nie tylko były lokalnymi centrami edukacji i rekreacji, ale ustanawiały poziom życia niedostępny nigdzie indziej, co sprzyjało osadnictwu i pracy na rzecz osiągnięcia statusu obywatela Rzymu. 
Antyczne wzorce zostały zachwiane wraz z upadkiem imperium. W średniowieczu łaźnie publiczne nie osiągały już ani takiego rozmachu ani wpływu na mieszkańców. Wraz z rozwojem cywilizacyjnym zachodu i zwiększoną świadomością medyczną, powstawały ośrodki uzdrowiskowe i termalne, aż po większe baseny i pływalnie. Pod koniec XX wieku rozpoczęto budowę pierwszych aquaparków, które to wróciły do wzorców łaźni rzymskich. Wydawać by się mogło, że rozrywka i sport na zawsze oderwały się od kultury i sztuki, jaka była reprezentowana w ramach wielkich kompleksów term Karakalli i innych.

\section{EDUKACJA POPRZEZ ZABAWĘ, CZYLI AQUAPARKI 3.0}

Wielkim wyzwaniem dzisiejszych czasów staje się walka z nieprawdą, brakiem logicznego myślenia, co prowadzi do zacofania kulturowego i w dalszej perspektywie do upadku naszej cywilizacji. Rosnący w siłę ruch płaskoziemców obnaża poziom kulturowy społeczeństwa. W dobie internetu umiejętność logicznego analizowania podawanych informacji jest kluczowa w ocenie jej wartości.

Czy rolą aquaparków jest edukacja? Obiekty te kojarzone są przede wszystkim ze sportem i z rekreacją, ale przecież wzorce antycznych term świadczą o tym, iż można łączyć te funkcje. Ówczesne biblioteki, będące częścią kompleksu łaźni rzymskich, stanowiły swego rodzaju centra naukowe. Wobec powyższego mniej już szokuje przypadek Wodnego Parku Tychy, który został zaprojektowany z myślą o symbiozie części sportowo-rekreacyjnej z wodną akademią, będącą nowoczesnym interaktywnym centrum edukacyjnym. Przestrzeń została bardzo bogato wyposażona w 32 stanowiska. Całość podzielona została na pięć zróżnicowanych scenograficznie stref tematycznych, ułożonych w spójną trasę. Motywem przewodnim był szeroko rozumiany żywioł wody. Punkty wiedzy zaprojektowano tak, aby dotyczyły różnych zagadnień, takich jak propagacja fal wodnych, tworzenia się tsunami, załadunku kontenerowego, tworzenia depresji, czy sposobów oczyszczania wody w mieście. Wiedza ta została przekazana za pomocą modeli, ekranów dotykowych czy zajęć sprawnościowych, które mają pobudzić wyobraźnie najmłodszych, jednocześnie stanowiąc powód refleksji dla opiekunów. Tego typu rozwiązania można zakwalifikować jako aquaparki 2.0, gdyż nawiązują one do obiektów takich jak słynne Centrum Kopernika w Warszawie, gdzie wiedza jest przekazywana poprzez interaktywne eksponaty, w odróżnieniu od gablot w dawnych polskich muzeach.

Edukatorium staje się współczesnym nośnikiem wiedzy, niczym rzymskie biblioteki, jednak nowością staje się opcja sprawdzenia zdobytej wiedzy. Wszystkie urządzenia zostały wyposażone w czujniki RFID, które połączone z systemem ESOK, umożliwiają weryfikację uczestników oraz ich wyników. Jednocześnie już na tym etapie, w obiekcie zastosowano grywalizację ${ }^{6}$, gdyż wyniki są porównywalne z innymi uczestnikami, co wpływa na rywalizację i chęć do podnoszenia swojej wiedzy. W dobie nadmiaru informacji miejsce takie staje się gwarantem wysokiej jakości przekazywanej wiedzy. 
Kolejny etap, multimedialna gra interaktywna, zaprojektowano już wewnątrz samego obiektu, wśród typowych atrakcji wodnych - czyni Wodny Park Tychy aquaparkiem trzeciej generacji. Wnętrze zostało ukształtowane w ramach grywalizacji architektury. Krzywoliniowe wnętrza zostały tak zaprojektowane, aby ich eksploracja odbywała się stopniowo. Niczym nauka, poznanie wymaga wysiłku i czasu. Architektura wykorzystuje odczucia uzyskiwane w grach w światach wymyślonych czy wręcz wirtualnych, przekładając je na świat rzeczywistych form. W obiekcie skrzętnie ukryto wiele artefaktów i zagadek, które niczym Indiana Jones trzeba odkryć i rozwiązać. W Wodnym Parku Tychy motywem przewodnim gry jest ekologia i wzbudzanie świadomości ludzi o konieczności oszczędzania wody i wykorzystywania odnawialnych źródeł energii. Rozwiązania cyfrowe przeplecione są z analogowymi. Konieczne jest ciągłe przemieszczanie się, co wymusza aktywne spędzanie czasu. Forma multimedialna zapewnia znalezienie wspólnego języka z dzisiejszą młodzieżą, którą najbardziej trzeba inspirować i zarażać pasją do nauki.

\section{DOSTĘPNOŚĆ AQUAPARKÓW DLA WSZYSTKICH GRUP SPOŁECZNYCH}

Dzisiejsze obiekty aquaparkowe są projektowane z myślą o dostępności, dla osób starszych i niepełnosprawnych. Obiekt Wodny Park Tychy opiera się na tym założeniu, poprzez przystosowanie strefy sportowej, za pomocą ruchomego dna, do zajęć grupowych, gdzie ww. grupa społeczna otrzymuje ciekawy pakiet usług, takich jak aqua-spinning, aqua-aerobik czy aqua-fitness. Bazując na badaniach przeprowadzonych w Ekwadorze przez Uniwersytet De Jaen w Hiszpanii, na osobach powyżej 60 roku życia, które jednoznacznie wskazują, iż aktywność fizyczna na basenach znacząco poprawia stan fizyczny, jak także psychiczny badanych. Okres testów wynosił 20 tygodni. Program ćwiczeń spowodował znaczącą redukcję tłuszczu i delikatny wzrost masy mięśniowej. Jednocześnie wodna aktywność przeciwdziałała sarkopenii, a psychologicznie umożliwiała badanym wzrost poczucia bezpieczeństwa i unikania upadkom. Odnotowano również poprawę ruchową, metabolizmu u wszystkich badanych. Podobny test został przeprowadzony przez portugalskich i brazylijskich badaczy przez okres 12 miesięcy, by wskazać jak wpływ aktywności fizycznej wpłynął na codzienne czynności seniorów, integrację społeczną oraz pamięć.

Badania przeprowadzone w Stanach Zjednoczonych na temat poziomu aktywności fizycznej i zwyczajów młodzieży wskazują na pandemię otyłości. Już jedna trzecia dzieci w wieku przedszkolnym i połowa w wieku szkolnym ma problem z nadwagą, w wieku dorosłym utrzymuje nadwagę lub ich stan znacząco się pogarsza. Brak zdrowia fizycznego przekłada się na dramatyczne zwiększenie zachorowań na cukrzycę typu II czy problemy ortopedyczne. W konsekwencji nadwagi pojawiają się problemy psychiczne. Otyłość wśród dzieci jest nieakceptowana i naraża te osoby na szykany ze strony rówieśników, doprowadzając do niskiej samooceny, która będzie towarzyszyć tym ludziom do końca ich życia. Badania wykazały, że 
młodzież żyjąca na obszarach wiejskich jest bardziej podatna na nadwagę i brak ruchu niż ich rówieśnicy z ośrodków miejskich. Te czynniki skłaniają najmłodszych do ucieczki w świat gier komputerowych lub telewizji, pogłębiając ich problemy. Badanie wskazuje, że obecnie na terytorium Ameryki Północnej istnieje ponad tysiąc parków wodnych zarówno wewnętrznych, jak i zewnętrznych, z których ponad $60 \%$ to obiekty prywatne. Jednocześnie branża notuje ciągły wzrost ilości obiektów wodnych zwłaszcza całorocznych placówek. Przeprowadzone testy na grupie kontrolnej wykazały, iż uczestnictwo i infrastruktura sportowa na miejscu znacząco wpływa na poprawę zdrowia i walkę z otyłością wśród dzieci.

Kolejną niepokojącą tendencją naszego społeczeństwa jest dynamiczny wzrost zachorowań na depresję. Codzienny pośpiech i stres sprzyjają pogłębianiu się tych zjawisk, dlatego tak kluczowa jest rola aquaparków w promowaniu zdrowego trybu życia, wypoczynku, relaksu. Rozpatrywany przykład Parku Wodnego Tychy został zaprojektowany w celu stworzenia wielu stref wypoczynku, dostosowanej do potrzeb różnych użytkowników posiadających skrajnie odmienne potrzeby. Budynek podzielono na strefy: sportową, gdzie również można odnaleźć basen do nauki pływania z opcją podnoszonego dna, wokół którego organizowane są zajęcia grupowe, oraz rekreacyjną, gdzie relaks miesza się z aktywnym wypoczynkiem. Układ zamyka saunarium wraz z przestrzeniami do schładzania oraz wypoczynku po intensywnych rytuałach. Uzupełnieniem tej strefy jest łaźnia piwna i wellness, w którym znalazły się baseny flotacyjne ${ }^{7}$, jednokomorowe i przestrzenne dla par, przystosowane do medytacji. Rozwinięcie stanowią masaże oraz wulkaniczne maty do radioterapii. Wszystkie te rozwiązania mają na celu oderwanie od przytłaczającej nas rzeczywistości, do przeniesienia nas mentalnie na jednodniowe wakacje.

\section{PODSUMOWANIE}

Wodny Park Tychy, często uważany za aquapark trzeciej generacji łączy ze sobą rekreację wodną, centrum edukacyjne i sporty siłowe w znaczący sposób nawiązując do antycznych wzorców, a dzięki wykorzystaniu grywalizacji architektury, wprowadza nową jakość. Rzymska funkcjonalność zostaje w końcu rozszerzona, dając zupełnie nowe możliwości i kierunki rozwojowe. Powstałą infrastrukturę można w łatwy sposób modyfikować i dostosowywać do nowych wyzwań i wymogów zarówno estetycznych, jak i technicznych, które zaistnieją w przyszłości. Bez konieczności przerabiania całego wnętrza czy zewnętrznej bryły można tworzyć niezliczone kombinacje rozwiązań. Wielozadaniowość jak i użyte technologie mogą stać się odciskiem naszych czasów w historii architektury.

Wobec powyższego, analizując przedstawiony przypadek Wodnego Parku Tychy, stwierdzić można, że poprzez odpowiednie dobranie funkcji i atrakcji możliwym jest spełnienie wszystkich wskazanych ról stawianych obiektom rekreacji wodnej XXI wieku. Jednocześnie staje się zalążkiem standardów dla innych obiektów tego typu. 
Zapewnienie sportu i edukacji w ramach tego typu obiektów umożliwia przeciwdziałanie negatywnym skutkom rozwarstwieniu się społeczeństwa. Umożliwia w równym stopniu dostęp do zweryfikowanej informacji, która to jest tak trudna do uzyskania w erze informacji. Centra edukacyjne jednocześnie wspierają logiczne myślenie i zachęcają do analizowania faktów. Społeczeństwo wyposażone w tego rodzaju ośrodki popełnia statystycznie mniej przestępstw i jest mniej agresywne, czego dowodzą badania w USA.

Dostępność obiektów typu term rzymskich od zawsze sprzyjała integracji i zapewniała rozrywkę wszystkim grupom społecznym, a jednocześnie wspierała witalność i dobre samopoczucie. W dobie nasilenia się chorób cywilizacyjnych tym bardziej konieczne jest kontynuowanie tego trybu funkcjonowania obiektów basenowych i rekreacyjnych. Wspieranie tym samym osób starszych umożliwia im dłuższe pozostanie aktywnym i zdrowym. Chroni przed poważnymi urazami i chorobami. Jednocześnie rywalizacja i możliwość spotkania rówieśników sprzyja rozwojowi zarówno fizycznemu, jak i psychicznemu dzieci i młodzieży.

Podziękowanie za udostępnienie materiałów dla Schick Architekci sp. z.o.o sp.k. ul. Niedurnego 99C Ruda Śląska 41-709 - studium przypadku Wodny Park Tychy, dokumentacja techniczna, analiza projektu budowlanego i wykonawczego pod kqtem zastosowanych rozwiqzań materiałowych i funkcjonalnych.

Szczególnie podziękowania dla Tiago Diasa, który pomógł w tłumaczeniu tekstów portugalskich oraz hiszpańskich.

\section{PRZYPISY}

1 Zgodnie z Rozporządzeniem Ministra Infrastruktury z dnia 18.05.2004 r. w sprawie określenia metod i podstaw sporzq̨dzania kosztorysu inwestorskiego, obliczania planowanych kosztów prac projektowych, jak również według klasyfikacji IARP załączonej w Regulamin Honorariów Architekta z 23.10.2003 (tekst ministerialny).

2 Osób przebywających w różnych strefach obiektu, takich jak: obuta, „nagiej stopy”, stref nietekstylnych, bezpieczeństwa, obsługi, ratownictwa, gastronomi, chemii itp.

3 Stanowi miejsce rozrywki i punkt spotkań, rozwoju kultury fizycznej, utrzymania dobrego samopoczucia, zdrowia.

4 Takich jak basenów, łaźni, spa, sal gimnastycznych, boisk do gry, galerii sztuki i domów handlowych, restauracji, filie bibliotek głównych (które w owym czasie pełniły rolę skarbnicy wiedzy dostępnych dla większego ogółu), ringów walki.

5 W Polsce już blisko dwukrotnie więcej ludzi popełnia samobójstwo niż ginie na drogach. Według raportu Komendy Głównej Policy w 2016 roku próbę samobójczą przeprowadziło 9861 osób, z czego 5406 odebrało sobie życie (4638 mężczyzn i 767 kobiet, głównie w wieku 25-34), w tym samym czasie na drogach zginęło 2993 osoby. 
6 Grywalizacja (ang. Gamification) - wykorzystanie mechaniki wykorzystywanej w grach fabularnych lub komputerowych do wpływania na ludzkie zachowania i emocje w sytuacjach codziennych innych niż gry i zabawa. W efekcie osoby uczestniczące w procesie grywalizacji zwiększają swoje zaangażowanie w realizację założonych celów edukacyjnych (np. różnego rodzaju aplikacje do nauki języków obcych, portal logowania do aeroklubu śląskiego).

7 Baseny te, wypełnione wodą o wysokim nasyceniu solą oraz podgrzane do temperatury ciała, mają dać wrażenie, poprzez odpowiednie oświetlenie i dźwięki, powrotu do łona matki, scalenia się ze wszechświatem.

\section{BIBLIOGRAFIA}

Aidar F., Silva A.J., Reis V.M., Carneiro A.L., \& Leite T.M., Doce y adulto viejo: actividades físicas acuáticos y la autonomía funcional, 5(5), 271-276, http://www.fpjournal.org.br/painel/ arquivos/640-1\%20Ativ\%20aquatica\%20idoso\%20Rev\%205\%202006\%20Espanhol.pdf.

Liu J., Bennett K.J., Harun N., \& Probst J.C., Urban-rural settings in overweight status and physical inactivity among US children aged 10-17 years, The Journal of Rural Health, 24(4), 407-415. PubMed, https://www.researchgate.net/publication/23471782_Urban-Rural_Di\$̧erences_in_Overweight_Status_and_Physical_Inactivity_Among_US_Children_Aged_10-17_Years

Singh Upinder, A history of ancient and early medieval India : from the Stone Age to the 12th century, Pearson Education, New Delhi 2008, 149-150.

Torres M.C. Teran, Efecto que tiene un programa de actividad fisica en el agua sobre las capacidades fisicas en un grupo de personas mayores de 60 anos, 2016.

Wang F., Wild T.C., Kipp W., Kuhle S., \& Veugelers P.J., The inluence of childhood obesity on the development of self-esteem, Health Reports, 2009, 20(2), 21-27, http://www.statcan. gc.ca/pub/82-003-x/2009002/article/10871-eng.pdf WATERPARKS' IMPACT ON RURAL COMMUNITIES.

William D.R., Craig M.R., An Examination of Physical Activity Levels and Use Patterns of Youth Participants, International Journal of Aquatic Research and Education Indoor Waterpark.

ADRES BIBLIOGRAFICZNY ARTYKUŁU: Truszczyński A., Rola miejskiego aquaparku XXI wieku w kontekście społeczno-ekonomicznych potrzeb. Analiza problemu na przykładzie Wodnego Parku Tychy, Przestrzeń/Urbanistyka/Architektura, 1/2018, s. 49-56. DATA AKCEPTACJI OSTATECZNEJ WERSII DO OPUBLIKOWANIA: 21.06.2018. 